\title{
Empirical analysis of regions of Mainland China's manufacturing efficiency promotion: Experience and lessons
}

\author{
Ma-lin Song ${ }^{1}$, Wei Zhang ${ }^{2 \star}$ and Jie $\mathrm{Wu}^{3}$ \\ ${ }^{1}$ School of Statistics and Applied Mathematics, Anhui University of Finance and Economics, Bengbu 233030, China. \\ ${ }^{2}$ School of Economics, University of Jinan, Shandong Jinan, China. \\ ${ }^{3}$ School of Management, University of Science and Technology of China, Anhui Hefei, China.
}

Accepted 7 July, 2011

\begin{abstract}
The manufacturing sector has been a decisive force in promoting economic development in China. According to the number of workers, net fixed assets and other economic data in China during 2000 to 2007, using data envelopment analysis (DEA) we can build a single-figure index reflecting the comprehensive manufacturing competitiveness of all regions. Based on those index and extension data of producer services, panel data are available and a model can be set up. After empirical analysis, the conclusion is as follows: the development of producer services in China is conducive to the promotion of manufacturing competitiveness, and one percent rise of the development of producer services can promote $2.6 \%$ of manufacturing efficiency. Along with these findings, we can put forward some suggestions for green producer services including improving the external environment, strengthening the cluster effect, promoting independent innovation, enhancing the level of opening up of producer service industry and so on.
\end{abstract}

Key words: Producer services, manufacturing competitiveness, data envelopment analysis, panel data.

\section{INTRODUCTION}

In the process of industrialization, the manufacturing sector has always been a decisive force in promoting economic development. China is in the middle stage of the process of industrialization, that is, heavy industry phase. The practice of world economic development has shown that at this stage, the manufacturing sector will promote the national economy entering a long period of rapid growth, while rapid economic growth will also provide opportunities to achieve leapfrog development of productive forces (Lu, 2006).

Since the reform and opening up, China's manufacturing sector has become the main driving force of sustained and rapid economic development. At the same time, its position in the international division of labor has

\footnotetext{
*Corresponding author. E-mail: cfy0510@gmail.com.
}

also been increasingly promoted. In 1980, China's manufacturing value added 515430 million yuan RMB, accounting for only $1.5 \%$ of the world. In 1990, the value accounted for $2.7 \%$ of the world's share, and China was a step ahead of Brazil into the world's top 10, ranking eighth, and ranking first among developing countries and regions. In 2000, China's share of manufacturing value added was $7.0 \%$, after the United States, Japan and Germany, and ranked fourth in the world's top 10. In 2004, China's share of global manufacturing increased to $10 \%$, rising to third in the world ahead of Germany (Wei, 2006). For this phenomenon, many scholars (Gu, et al., 2006; Tang and $\mathrm{Xu}, 2007$ ) have given explanation that China has an abundance of cheap labor and resources, forming a unique advantage which is hard to copy for other countries. There are also many scholars (Gao, 2005) who believe that it is difficult for China's manufacturing to become a pillar industry of national economy because 
lack of core technology and the production almost remains in the roughing stage. For these views, it is necessary for in-depth analysis to get logical conclusion, which can serve for realistic industry planning and policymaking.

\section{EMPIRICAL ANALYSES}

\section{Malmquist index and its decomposition of TFP}

Total factor productivity (TFP) Malmquist index and its decomposition is used to show the regional differences in Chinese manufacturing efficiency and the causes of change trend. Now that data used in this article is the provincial level panel data, therefore, in the analysis of China's TFP change in the manufacturing sector, the TFP Malmquist productivity index of the provinces in Mainland China yearly during 2000 to 2007 was calculated and broken down. Then, after the summary and average of provincial calculation results, the overall condition of TFP change in Chinese manufacturing sector was gotten.

According to related theories of the Malmquist TFP index and its decomposition results, we can look at manufacturing TFP change in various regions of China. In order to compare the difference of manufacturing TFP changes in different regions, based on the results of the analysis, we have divided China into Eastern China, Northeast China, Central China and Western China four regions. According to national administrative divisions, Eastern region includes; Beijing, Tianjin, Hebei, Shanghai, Jiangsu, Zhejiang, Shandong, Fujian, Guangdong and Hainan, Northeast region includes Liaoning, Jilin, Heilongjiang, Central region includes Shanxi, Anhui, Jiangxi, Henan, Hubei and Hunan, and Western regions includes Inner Mongolia, Guangxi, Sichuan, Guizhou, Yunnan, Tibet, Shaanxi, Gansu, Qinghai, Ningxia and Xinjiang. Concrete results are shown in Table 1 . To save space, here is only the list of the average of manufacturing Malmquist productivity index and its decomposition in the provinces of Mainland China during the years 2000 to 2007. In addition, the corresponding results of China's eastern, northeastern, central and western regions during 2000 to 2007 are shown in Table 2.

\section{The econometric analysis of competitiveness}

For most parts of China in the transition period, their levels of socioeconomic development have great imbalance, and there are much difference in aspects of political, legal, social status, institution building credibility and so on. Through a detailed analysis of the manufacturing sector as well as the construction of its statistical index system, the manufacturing sector can be considered to be an entity that outputs a certain number of "products" due to the input of a predetermined amount of variables required to produce the products. The progression from "input" to "output" must go through a decision making process in which each unit is referred to as a DEA technology unit in the decision-making process (decision making units, DMU). Data envelopment analysis (DEA), in particular, ultraefficient data envelopment model, has absolute advantage in handling those problems and effective evaluation of multi-input and multi-output. In view of this, we used this kind of unstructured (nonparametric) assessment methods. DEA model has many forms, from which we use extended DEA model - super efficiency evaluation model (Song and Yang, 2008). According to the data availability, we chose to sample timing interval from 2000 to 2007, crosssectional sample includes 30 provinces (cities, districts) in Mainland China except Tibet, and raw data comes from the "China statistical yearbook" corresponding to each year. There are two reasons to remove Tibet. First, Tibet is sparsely populated and many statistical data in industrial areas are lacking or are not comprehensive enough. Second, although there are a few manufacturing industries in Tibet, its economic contribution rate is very small. This would avoid the impact of the presence of abnormal values on empirical outcomes.

We set the total industrial output value and profit of manufacturing as the output in the DEA model, while input includes the number of manufacturing practitioners, fixed assets investment, liquidity, and the number of professional and technical personnel of manufacturing units in urban areas. The "number of professional and technical personnel of manufacturing units in urban areas" is the manifestation of human capital, on behalf of regional technical level, due to regional gap on level of technology same input may produce greatly different output, for which the introduction of this index has a certain degree of rationality.

On the assumption that scale economics is constant, we calculate the efficiency values of all provincial and urban manufacturing from 2000 to 2007 which are shown in Tables 3 and 4. Overall, the manufacturing efficiency shows an upward trend except for northeast region, despite there being some fluctuations. In this regard, we give the explanation as follow: Northeast region is China's old industrial base and infrastructure is relatively sound, resulting efficiency in the manufacturing sector maintained at a high level in 2000 and 2001. However, due to low technical progress index and lack of technological innovation-driven forces, it is difficult to maintain a relatively high level all the time. For eastern region, the high level of economic development and location advantages attract a large number of production factors (including the various types of senior professional and technical personnel, and capital investment from all aspects, etc.), allowing manufacturers to maintain a high level. In the "Rise of Central China" and the "Great Western Development" strategy implementation and the support of complementary policies, manufacturing efficiency levels of China's central and western regions show overall upward trend. Of course, each province's efficiency value does not always show an upward trend, since 2000 , the efficiency value of the majority of provinces and municipalities show the overall fluctuations in the performance of the expansion or contraction for the same period, which is the economic cycle effects (Gao, 2000). In addition, the higher value of manufacturing efficiency in Xinjiang is mainly due to the resources advantages the region has, and good posture of development and utilization, and the "Go West" strategy and border development strategy also promote its manufacturing efficiency level.

\section{RESULTS}

From the aforementioned analysis, we can see a high correlation of the index of total factor productivity and technological progress in China's manufacturing industry during 2000 to 2007. During this period, the growth of total factor productivity was mainly due to the improvement of technological progress, and the improvement of manufacturing technological progress was mainly promoted by producer services including technical research and development, financing and marketing. That is, the development of producer services can promote the manufacturing from big to strong and industrial upgrading, and improve the overall competitiveness of the manufacturing sector.

The views of scholars vary greatly about the definition 
Table 1. The average manufacturing Malmquist productivity index and its decomposition of each province (2000 to 2007$)$.

\begin{tabular}{|c|c|c|c|c|c|}
\hline Province & $\begin{array}{l}\text { Index of Malmquist } \\
\text { productivity }\end{array}$ & $\begin{array}{c}\text { Index of } \\
\text { technological } \\
\text { progress change }\end{array}$ & $\begin{array}{l}\text { Index of technical } \\
\text { efficiency change }\end{array}$ & $\begin{array}{c}\text { Index of pure } \\
\text { technical efficiency } \\
\text { change }\end{array}$ & $\begin{array}{l}\text { Index of scale } \\
\text { efficiency }\end{array}$ \\
\hline Beijing & 1.190 & 1.166 & 1.021 & 1.018 & 1.003 \\
\hline Tianjin & 1.117 & 1.123 & 0.994 & 0.994 & 1.000 \\
\hline Hebei & 1.132 & 1.116 & 1.014 & 1.012 & 1.002 \\
\hline Shanxi & 1.186 & 1.119 & 1.060 & 1.034 & 1.024 \\
\hline Neimenggu & 1.107 & 1.103 & 1.003 & 1.002 & 1.000 \\
\hline Liaoning & 1.118 & 1.118 & 1.000 & 0.998 & 1.001 \\
\hline Jilin & 1.201 & 1.137 & 1.056 & 1.03 & 1.025 \\
\hline Heilongjiang & 1.121 & 1.121 & 1.000 & 1.000 & 1.000 \\
\hline Shanghai & 1.172 & 1.172 & 1.000 & 1.000 & 1.000 \\
\hline Jiangsu & 1.151 & 1.151 & 1.000 & 1.000 & 1.000 \\
\hline Zhejiang & 1.185 & 1.201 & 0.987 & 0.999 & 0.987 \\
\hline Anhui & 1.106 & 1.089 & 1.106 & 1.011 & 1.005 \\
\hline Fujian & 1.362 & 1.284 & 1.061 & 1.000 & 1.061 \\
\hline Jiangxi & 1.132 & 1.087 & 1.042 & 1.025 & 1.016 \\
\hline Shandong & 1.241 & 1.234 & 1.005 & 1.000 & 1.005 \\
\hline Henan & 1.110 & 1.081 & 1.027 & 1.021 & 1.006 \\
\hline Hubei & 1.047 & 1.062 & 0.986 & 0.984 & 1.002 \\
\hline Hunan & 1.133 & 1.097 & 1.033 & 1.028 & 1.005 \\
\hline Guangdong & 1.132 & 1.132 & 1.000 & 1.000 & 1.000 \\
\hline Guangxi & 1.066 & 1.073 & 0.993 & 0.990 & 1.003 \\
\hline Hainan & 1.236 & 1.182 & 1.046 & 1.000 & 1.046 \\
\hline Chongqing & 1.118 & 1.095 & 1.020 & 0.994 & 1.027 \\
\hline Sichuan & 1.122 & 1.081 & 1.038 & 1.033 & 1.005 \\
\hline Guizhou & 1.129 & 1.057 & 1.068 & 1.029 & 1.038 \\
\hline Yunnan & 1.156 & 1.140 & 1.014 & 1.005 & 1.009 \\
\hline Shaanxi & 1.130 & 1.084 & 1.042 & 1.033 & 1.009 \\
\hline Gansu & 1.099 & 1.057 & 1.040 & 1.018 & 1.022 \\
\hline Qinghai & 1.039 & 1.053 & 0.986 & 0.981 & 1.006 \\
\hline Ningxia & 1.140 & 1.127 & 1.012 & 0.977 & 1.035 \\
\hline Xinjiang & 1.129 & 1.129 & 1.000 & 1.000 & 1.000 \\
\hline
\end{tabular}

Source: Using DEA model, calculated according to annual Statistical Yearbook of China and Macro-China database.

on the producer services. Martinelli, a foreign scholar, believes that producer services should include the activities relating to the allocation of resources and logistics, technological innovation and management and so on (Martinelli, 1991). In the later studies, other foreign scholars proposed that the producer services should include parts of transportation services, wholesale services and cleaning services provided for enterprises and so on (Gao, 2005). Domestic scholars pointed out that producer services are the intermediate services provided for the production process directly or indirectly ( $\mathrm{Li}, 2002)$, including technology, capital and human resources directly regarded as the intermediate inputs of industrial enterprises, distribution and financial services as part of commodity exchange process, and the services needed for the formation of human capital compatible with the new production structure (Tang and $\mathrm{Xu}, 2007$ ). The writers think that, in the narrow sense, the producer services primarily refer to the technical research and development services provided for the industrial production, financial services and marketing services. Among them, the core one is the research and development service, which directly determines the capability of independent innovation of manufacturing sectors, further determines the core competitiveness of the manufacturing sectors, and is the key factor affecting the manufacturing efficiency.

Some scholars believe that the producer services provide an effective support for the development of the manufacturing industry. This conclusion is a good answer 
Table 2. Malmquist productivity index and its decomposition of China's manufacturing in four regions (2000 to 2007).

\begin{tabular}{lccccc}
\hline Area & $\begin{array}{c}\text { Index of } \\
\text { Malmquist } \\
\text { productivity }\end{array}$ & $\begin{array}{c}\text { Index of } \\
\text { technological } \\
\text { progress change }\end{array}$ & $\begin{array}{c}\text { Index of technical } \\
\text { efficiency change }\end{array}$ & $\begin{array}{c}\text { Index of pure } \\
\text { technical efficiency } \\
\text { change }\end{array}$ & $\begin{array}{c}\text { Index of } \\
\text { scale } \\
\text { efficiency }\end{array}$ \\
\hline National mean value & 0.9186 & 0.9180 & 1.0006 & 0.9984 & 1.0023 \\
Eastern mean value & 1.1918 & 1.1761 & 1.0128 & 1.0023 & 1.0104 \\
Northeast mean value & 1.1467 & 1.1253 & 1.0187 & 1.0093 & 1.0087 \\
Centralmean value & 1.1190 & 1.0892 & 1.0423 & 1.0172 & 1.0097 \\
Western mean value & 1.1123 & 1.0908 & 1.0196 & 1.0056 & 1.0140 \\
\hline
\end{tabular}

Source: Using DEA model, calculated according to annual Statistical Yearbook of China from 2001 to 2008 and Macro-China database.

Table 3. Manufacturing efficiency of Mainland China's provinces and municipalities.

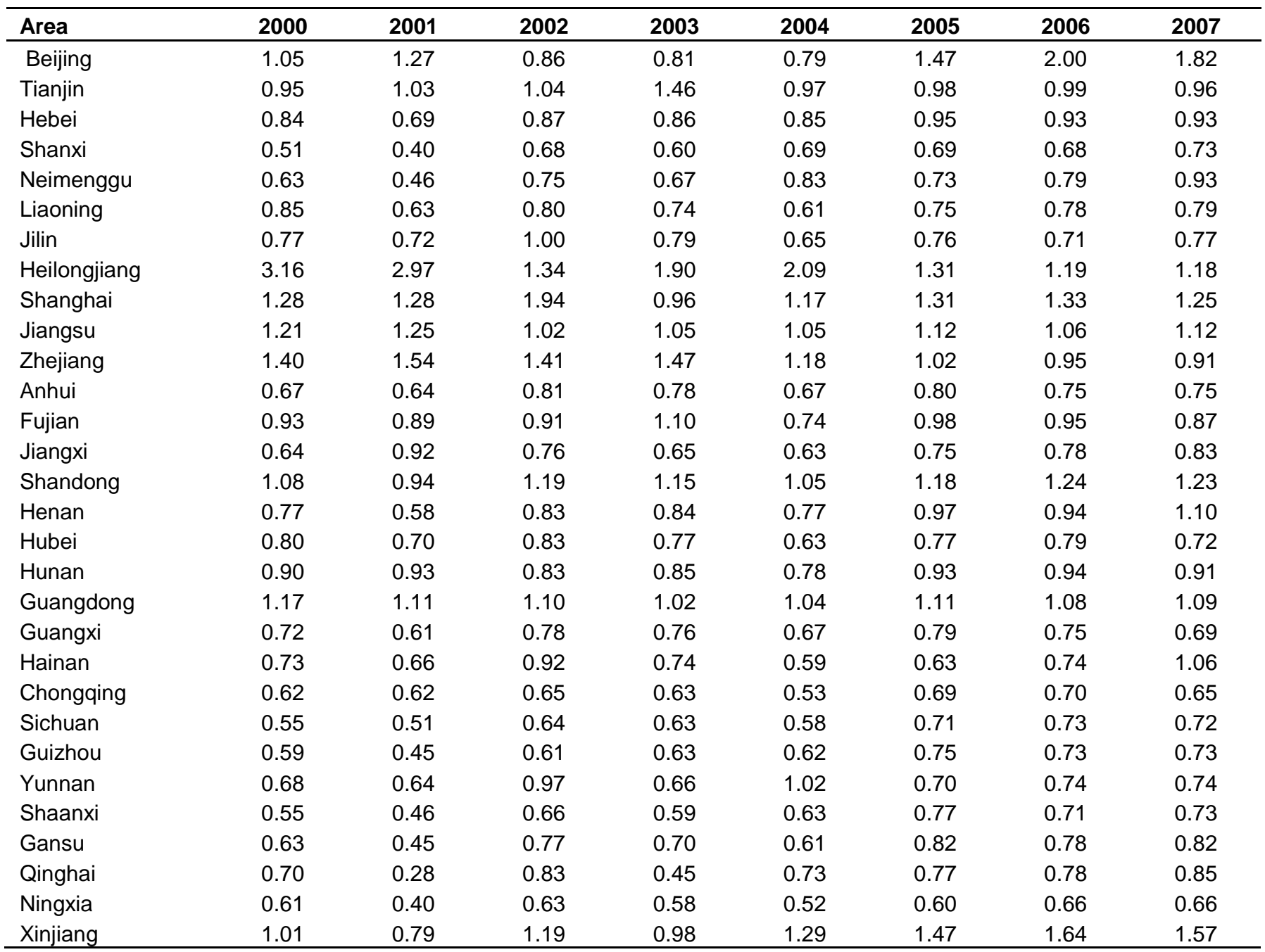

Source: Calculated based on the super-efficiency DEA model.

to the former question, namely, the answer to the reason of the efficiency promotion of China's manufacturing industry lies in the vigorously developing producer services. Karaomerliogln and Carlsson (1999) thought the 
Table 4. The comparison of manufacturing efficiency level of Mainland China: Eastern, Northeast, Central and Western areas (2002 to 2007).

\begin{tabular}{lcccccccc}
\hline Area & $\mathbf{2 0 0 0}$ & $\mathbf{2 0 0 1}$ & $\mathbf{2 0 0 2}$ & $\mathbf{2 0 0 3}$ & $\mathbf{2 0 0 4}$ & $\mathbf{2 0 0 5}$ & $\mathbf{2 0 0 6}$ & $\mathbf{2 0 0 7}$ \\
\hline National mean value & 0.9099 & 0.8343 & 0.9301 & 0.8677 & 0.8429 & 0.9167 & 0.9357 & 0.9367 \\
Eastern mean value & 1.0638 & 1.0669 & 1.1259 & 1.0618 & 0.9435 & 1.0741 & 1.1264 & 1.1244 \\
Northeast mean value & 1.5959 & 1.4390 & 1.0478 & 1.1442 & 1.1168 & 0.9390 & 0.8940 & 0.9121 \\
Central mean value & 0.7156 & 0.6935 & 0.7903 & 0.7452 & 0.6950 & 0.8186 & 0.8129 & 0.8407 \\
Western mean value & 0.6626 & 0.5150 & 0.7710 & 0.6607 & 0.7290 & 0.8003 & 0.8189 & 0.8252 \\
\hline
\end{tabular}

Source: Summarized and calculated from Table 3.

the producer services as a part of the whole manufacturing sector because of its complement and support for manufacturing sector. Producer services rely on the development of manufacturing; generally speaking, the manufacturing services companies are located closely to the region of industry cluster near to suppliers and customers, however, in the after-industrialized countries, especially, central business district of some cities, the producer services continue to open branches in the manufacturing-intensive regions of own country or foreign ones (Martinelli, 1991). Although the considerable part of enterprises served for the production are affected by the development of manufacturing sector, some production service companies do not subject to the impact of migration trends of the manufacturing sector, the reason of which is that these producer services have the flexibility to restructure and adjust themselves (Gu et al., 1999). Tang and $\mathrm{Xu}$ (2007) derive from the foreign research experience that producer services serving for the manufacturing have the management, promotion and strategic functions. The infrastructures of economic development including transport, telecommunications, commerce, finance, and so on, have a strong external economy. Efficiency promotion of these services can promote deepening of division of labor by reducing cost of division of labor by reducing transaction costs, thus promote the development of manufacturing sectors. So, it is not a simple causal relationship between producer services and manufacturing, but a continuously strengthened interdependence. First of all, the producer services facilitate the deepening of division of labor. It drives intermediate demand by introducing the increasingly specialized human capital and intellectual capital to commodity-producing sectors which is are mostly related to information collection, collation, processing and production of commodity production, circulation and consumption, resulting in the organizational structure change of industrial production and deepening of division of labor. Secondly, the producer services constitute the essential links of value chain of modern industry. Production activities of enterprises can be divided into three links: the upstream link composing by product development and procuring management, the middle link composing by production and processing, and the downstream link composing by product shipping, marketing and aftersales service. Among these three links, the producer services are at upstream and downstream links and add value to the companies though technical research and development, management consulting, engineering design, finance and insurance, transportation and communication, and other activities. Assuming the corresponding model for the equation:

$$
E F F_{i t}=c_{1}+\alpha_{1} P S R_{i t}+u_{i t}
$$

Where, i represents the cross-section observation data, $t$ is the observation year of the seven years 2000-2007, $\alpha$ is slope coefficient, $u_{i t}$ refers to the individual effect of the province i. EFF is competitiveness of the manufacturing sector, say, the value of DEA efficiency, PSR represents the weight of value-added of producer services on the total GDP.

Econometric theory suggests that number of economic variables, particularly, panel data, are mostly nonstationary variables, which have a performance of spurious regression to a large extent when used to make regression analysis. In order to avoid that, it is necessary to make unit root and co-integration tests for panel data.

In order to avoid false regression, unit root test must be conducted before regression analysis. Different from these of time-series data unit root test, the methods of panel unit root test mainly include: methods of same root test, such as, LLC test (Levin et al., 2002), Breitung test (Breitung and Jorg, 2000) and Hadri test (Hardi and Kaddour, 2003), methods of different roots test, such as, IPS test (Im et al., 2003), Fisher -ADF and PP-Fisher test (Maddala and Wu, 1999). The original hypothesis of LLC test, Breitung test, IPS test and Fisher-ADF test contain unit root, and that of Hadri test does not contain unit root. In this paper, LLC test, Fisher-ADF and PP-Fisher test are all adopted, and all data and variables used by the panel unit root test are shown in Table 5. The results of these tests show that the variables in this model are the non-smooth ones. So we proceed to have a cointegration test to determine whether it is spurious regression. Co-integration equation: 
Table 5. Unit root test of panel data.

\begin{tabular}{llcc}
\hline Test method & & Manufacturing DEA efficiency value (MEV) & Producer services rate (PSR) \\
\hline \multirow{3}{*}{ Level value } & LLC Test & $2.9046(0.9982)$ & $-7.0173(0.0000)^{\star \star \star}$ \\
& Fisher-ADF test & $25.4017(1.0000)$ & $38.0602(0.9879)$ \\
& PP-Fisher chi-square & $32.8477(0.9983)$ & $64.4223(0.3247)$ \\
\hline
\end{tabular}

${ }^{* * *}$ represents s significant level of $1 \%$.

Table 6. Panel co-integration test of variables used in this paper.

\begin{tabular}{|c|c|c|c|c|c|c|c|}
\hline \multirow[t]{2}{*}{ Variable } & & \multicolumn{6}{|c|}{ Panel co-integration test results } \\
\hline & & $\begin{array}{l}\text { Group } \\
\text { statistics }\end{array}$ & $\begin{array}{c}\text { Non- } \\
\text { weighted }\end{array}$ & $\begin{array}{c}\text { Panel v-stat } \\
-2.43\end{array}$ & $\begin{array}{c}\text { Panel rho-stat } \\
1.63^{*}\end{array}$ & Panel PP-stat $-3.40^{\star \star *}$ & $\begin{array}{c}\text { Panel ADF-stat- } \\
3.98^{\star \star \star}\end{array}$ \\
\hline \multirow{2}{*}{$\begin{array}{l}\text { Explanatory } \\
\text { variable } \\
\text { (PSR) }\end{array}$} & $\begin{array}{l}\text { Explained } \\
\text { variable }\end{array}$ & & Weighted & -3.12 & $-1.56^{*}$ & $-3.04^{\star \star *}$ & $-4.41^{\star \star *}$ \\
\hline & & $\begin{array}{r}\text { Intel } \\
\text { St }\end{array}$ & $\begin{array}{l}\text { Dups } \\
\text { ics }\end{array}$ & & $\begin{array}{c}\text { Group rho-stat } \\
2.34 \\
\end{array}$ & $\begin{array}{c}\text { Group PP-stat - } \\
3.88^{\star \star \star} \\
\end{array}$ & $\begin{array}{c}\text { Group ADF-stat } \\
6.13^{\star \star \star}\end{array}$ \\
\hline
\end{tabular}

Table 7. Test results of hypothesis.

\begin{tabular}{lcccc}
\hline Explanatory variable & Correlation & Standard deviation & T value & Accompanied probability \\
\hline C & $0.6290^{\star *}$ & 0.1179 & 5.3349 & 0.0000 \\
PSR & $2.6034^{* *}$ & 1.1358 & 2.2920 & 0.0234 \\
$\mathrm{R}^{2}$ & & & 0.7221 & \\
D.W value & & & 1.7148 & \\
F statistics & & & 10.6926 & \\
Sample & & & 180 & \\
\hline
\end{tabular}

${ }^{* * *}$ represents a significant level of $5 \%$.

$y_{i t}=\alpha_{i}+\beta_{i} x_{i t}+\varepsilon_{i t}, t=1,2, \ldots, \quad i=1,2, \ldots, N$

The result of panel co-integration test of variables is shown in Table 6 . In all of co-integration test statistics in this equation, at the $10 \%$ significant level, there are 8 refusing the original hypothesis which states that there is no co-integration relationship, and 3 accepting the original hypothesis, from which we can deduce that the equation has co-integration relationship and can be conducted by regression analysis.

By modeling of Eviews5.1 software, we select the intercept model of constant independent variable coefficients and fixed effects. After the un-weighted least squares regression analysis, we can get the results in Table 7. As can be seen from the table, producer services have a significant role in promotion of manufacturing competitiveness. Its coefficient is 2.6034 , $p$ value is significantly smaller than 0.05 , and DW value is close to 2 , so that the model fit better. We can deduce that every increase of $1 \%$ of producer services development level will drive $2.6034 \%$ point rise of manufacturing efficiency, and producer services become

a propeller of manufacturing promotion.

\section{INSPIRATION: DEVELOPING GREEN PRODUCER SERVICES}

China should learn from international experience, and strongly encourage and support the development of producer services. Lin and Hsieh (2011) analyzed effect of relationships in supply networks of a long-term analysis in the automotive industry. Lin and Lu (2011) have analyzed the influence of operating strategies and firm's characteristics on factor productivity in Taiwan. Considering combination with the reality that China is deeply troubled by environmental pollution, we believe the best way is to develop green producer services, namely, to actively develop low-pollution, low-cost manufacturing service industries. However, the situation is a little different from the past. The outbreak of American 
financial crisis makes not only U.S. economy into a prolonged recession but also world's and China's economy hard to escape from the crisis because of the gradual deepening of global economic integration. In this case, it is necessary to consider the background of U.S. financial crisis when formulating measures developing green producer services, so we propose the counter-measures "one-raising, two-improving, three-enhancing".

First of all, it is needed to raise the level of opening up of green producer services. Into the $21^{\text {st }}$ century, the global economy has come to further transform to service industries trends. Meanwhile, the core of economic globalization has begun to experience a transition from manufacturing to service industries. In view of this situation, we should see the green producer services in a global outlook and transform the adverse effects of U.S. financial crisis into favorable factors, to make costeffectively use of global resources, participate in the international division of labor, and develop cross-border management in a wider scope and higher level. We need to seize the historic opportunity that international capital transfers to the service industry, and appropriately reduce the entry barriers of foreign producer services, to attract multinational companies of an excellent operating service coming to China to set up regional headquarters and centers of research and development, settlement, procurement and so on.

What's more, we should take certain measures to encourage the spread of innovation in their full effect, driving China's green producer services to upgrade to an better technology and management level, and build a low resource consumption, high value-added and employment-absorbed industrial system. At the same time, the producer services should carry out the "going out" strategy and establish service centers of overseas investment, providing marketing, brand building, research and development, marketing services for companies willing to go out.

Secondly, more effort should be made to improve the hard environment of green producer services. Seen from the experiences of developed countries promoting the development of producer services, infrastructures, particularly logistics facilities, play an important supporting role in healthy and rapid development of producer services. In recent years, China increasingly invests in infrastructure, creating a good condition for development of producer services. However, compared with developed countries, there is a certain gap. After U.S. financial crisis, the United States, Canada and other developed countries had taken measures by creasing public spending to stimulate economic recovery, and China also introduced 4 trillion Yuan investment program to expand domestic demand. To this end, it should use this opportunity to guide the local government investment reasonably, and choice construction projects of infrastructure associated highly with producer services, constantly expanding social consuming demand for green producer services. At the same time, try to bring supporting convergence of new projects with existing infrastructure, and improve infrastructure service functions through "fill the seats", break the barriers between cities and between regions, to form a mesh pattern of infrastructure services, form function-reasonable and being comparative advantages regional division of labor system by scientifically planning all kinds of infrastructures, and improve the efficiency of using infrastructure.

Thirdly, it is essential to gradually improve a good soft environment of producer services. Seen from the experiences of developed countries promoting producer services development, the soft environment including laws and regulations is an important precondition for rapid and healthy development of producer services. In order to promote development of financial services and enhance their competitiveness, the U.S. Congress in 1999 passed the "Financial Services Modernization Act", breaking the pattern of a separate operation and establishing mixed-operation financial system, and the United Kingdom in 1986 promulgated the "Financial Services Act", then in 2000 enacted the "Financial Services and Markets Act" to speed up the process of mixed operation. In aspects of promoting information services, as early as 60 years in the $20^{\text {th }}$ century, the United States promulgated the "Information Disclosure Law," and then enacted the "Federal Information Resources Management Regulations", "copyright laws", "Computer Software Protection Law" and the "Consumer Internet Privacy Protection Act" and so on. "U.S. Telecommunications Act" adopted in 1996 brought the U.S. service providers of information services new opportunities and challenges, the law not only allowed the United States long-distance companies, local telephone companies, utilities and cable service companies to compete with each other in the crucial communications and information field, at the same time, the U.S. telecommunications market was opened to foreign countries, introducing competition from abroad. This would undoubtedly stimulated innovation demand in the telecommunications industry in the United States, having it develop new technology to promote its adoption, improve service quality, increase public information, media, entertainment, business and education, information and databases of value-added services to compete with their rivals, allowing customers to eventually get more cost-effective products and services, which can be said that the announcement of the Telecommunications Act made United States competition in the field of information services and development enter a new period. These laws and regulations had played a very crucial role in promoting the appropriate development of service industries. In the past, our government also worked out many laws and regulations in this regard to promote the development of green producer services. However, it is not enough, and there are not comprehensive national laws 
and regulations, such as "Producer Services Promotion Law", "Guidance to promote development of producer services", etc. Furthermore, policies from the finance, taxation and human resources also needed to be provided.

The fourth inspiration is to enhance the gathering effect of green producer services. Gathering model chosen by producer services is its inevitable result of the pursuit of external economies of scale. Porter believes that Industrial agglomeration is defined as interconnections of a group of geographically-close and interactive enterprises and corporate bodies based on their commonalities and complementarities in a particular field. Markusen (1989) proposed that producer services showed its own characteristics of returns to scale incrementally which stimulates appearance of industrial cluster. Agglomeration will help the enterprises enjoy conveniently each other's services, increase the chance to achieve linkages forward and backward, help enterprises find more qualified talents and improve corporate reputation, also help lower information asymmetry between the corporation and customers, at the same time, enterprises can gain competitive advantage through learning by gathering. Internationally, the cluster development trend of producer services has been more and more obvious, such as the information service industry cluster in Silicon Valley, Wall Street's financial industry cluster and so on. China also has many successful stories about producer services cluster development, such as Zhongguancun information industry cluster, and Lujiazui financial services cluster in Shanghai. Future work should been focused on the development of producer services and actively promote the construction of professional nature of parks and industrial bases, further enhancing cluster effect of producer service. For example, we must vigorously develop the metropolitan central business district (CBD), City Circle and urban agglomerations, and build their cross-zones into centers of producer services, which attracts businesses around the region concentrating to the center.

The fifth inspiration is to enhance the capability of independent innovation of green producer services. Although enterprises can decide the model of access to technology by itself, China, a rising power, is facing an increasingly severe constraint of intellectual property rights. Therefore, it is necessary to promote independent innovation strategy no matter from a national level or a strategic level. According to statistics, the R\&D investment proportion of service firms in China, only $6.6 \%$, is not only the lowest of all industries, compared to medium hightechnology industries (31.1\%) and high-tech industries, but also the lowest of all listed OECD countries. Facing of the adverse effects of U.S. financial crisis, independent innovation capability has become the main way for producer services to increase market share and get excess profits. Besides increasing the $R$ and $D$ investment, the means to enhance independent innovation capability is also to introduce and cultivate strong R\&D personnel and management personnel, for example, we should take advantage of the opportunity of foreign economic downturn and widespread layoffs to attract foreign outstanding $R \& D$ personnel and management personnel in producer services to domestic enterprises. In addition to that, complying with the international trend, the government should encourage enterprises to do overseas $R \& D$ to enhance capability of independent innovation, and $R \& D$ internationalization is the business strategy of corporation response to the fierce international competition in the context of globalization. On the one hand, advances of information technology and modularity of $R \& D$ activities make overseas R\&D of enter-prises possible. On the other hand, overseas R\&D can endue companies some advantages: one is getting closer to the market of host country and improving the competitiveness of product markets, the other is making use of the R\&D resources of host country, particularly, the human resources, to enhance the R\&D level or reduce costs. With the global transfer of manufacturing to China, the mainstream of internationalization of domestic enterprises is not to build factories abroad, but to set up overseas $R \& D$ centers.

The sixth inspiration is to enhance supervision and regulation for green producer services. Besides introducing laws and regulations to support the producer services, supervision and regulation, especially for the financial services is also essential. The outbreak of U.S. financial crisis is not unrelated to "Financial Services Modernization Act" pushing the U.S. economy gradually moving toward virtualization and excessive liberalization and resulting in the flooded financial derivative products. The bill made people relaxed in financial regulation, eventually leading to the happening of crisis. In this regard, we must take warning from it. The purpose of strengthening supervision is to ensure healthy development of the green producer services and achieve its long-term sustainable development. Specifically, we should establish and make perfect credit record of market, form sharing mechanism of business credit information, establish and make perfect the trustworthy incentive mechanism and dishonesty disciplinary mechanism, advocate honesty services to create a fair and orderly trading order.

Meanwhile, people should focus on anti-unfair competition, safeguard the legitimate rights and interests of consumers, and enhance contract supervision, cracking down illegal behavior and protecting the interests of operators and consumers.

\section{Conclusions}

The answer to the reason of efficiency promotion of China's manufacturing is the development of producer services. Service industry indeed has a significant role in 
enhancing the competitiveness of the manufacturing. First of all, the producer services promote the deepening of the division of labor. Secondly, the producer services constitute an important link in the value chain of modern industries. Finally, the service sector promotes productive economic growth. The measuring results in this paper show that one percentage ascension of producer services can drive up $2.6034 \%$ of manufacturing competitiveness. Considering this distinctive relationship between producer services and manufacturing efficiency and the importance of protecting environment, we propose to vigorously develop the green producer services, specifically including: raise the level of opening up of green producer services, improving the hard environment of green producer services, improving gradually a good soft environment of green producer services, enhancing the gathering effect of green producer services, enhancing the capability of independent innovation of green producer services, enhancing supervision and regulation for green producer services, and so on. We believe that the development of producer services will help promote the development of China's manufacturing, and further promote China's economic growth. Given the condition of saving energy, developing green producer services is an inevitable choice for China's future development.

\section{ACKNOWLEDGEMENTS}

This research was supported by the Technology development projects in Shandong, China (2008RKA086 and 2009GG10010003), National Natural Science Funds of China (No. 70821001, 70901069 and 71171001), Research Fund for the Doctoral Program of Higher Education of China for New Teachers (No. 20093402120013), The Fundamental Research Funds for the Central Universities (No. WK2040150007).

\section{REFERENCES}

Breitung J (2000) "The local power of some unit root tests for panel data". In Baltagi B (ed), Advances in Econometrics, Vol. 15: Nonstationary Panels, Panel Co-integration, and Dynamic Panels, Amsterdam: JAI Press, pp. 161-178.

Gao CL (2005). "Literature review: The concept, features and location of producer services". Shanghai Econ. Rev., 11: 64-70.

Gao HY (2000). "Western economics". China Renmin University Press, Beijing. pp. 821-824.

Gu NH, Bi DD, Ren WB (2006). "Relationship between producer services' development and manufacturing's competence in China during transition period". China Industrial Econ., 9: 14-21.

Im KS, Pesaran MH, Shin Y (2003). "Testing for unit roots in heterogeneous panels". J. Econ., 115(1): 53-74.

Kaddour H (2000). "Testing for stationarity in heterogeneous panel data". Econ. J., 3(2): 148-161.

Karaomerliogln D, Carlsson B (1999). "Manufacturing in decline? A matter of definition". Econ. Innov. N. Technol., 8(3): 175-196.

Levin A, Lin CF, James Chu CS (2002). "Unit root tests in panel data: asymptotic and finite-sample properties". J. Econ., 108(1): 1-24.

$\mathrm{Li} \mathrm{HM} \mathrm{(2002).} \mathrm{"Discussing} \mathrm{the} \mathrm{role} \mathrm{of} \mathrm{government} \mathrm{in} \mathrm{the} \mathrm{development} \mathrm{of}$ producer services". Stat. Res., 8: 63-66.

Lin CC, Hsieh CC (2011). "Effect of relationships in supply networks: A long-term analysis in the automotive industry". Afr. J. Bus. Manage., 5(7): 2531-2544.

Lin HW, Lu HF (2011). "The influence of operating strategies and firm's characteristics on factor productivity: Evidence from the lighting equipment industry in Taiwan". Afr. J. Bus. Manage., 5(9): 34573465.

Maddala GS, Wu S (1999). "A comparative study of unit root tests with panel data and a new simple test". Oxf. Bull. Econ. Stat., 61(0): 631652.

Martinelli F (1991). "A demand-oriented approach to understanding producer services". In Daniels PW, Moulaert F (eds.), The Changing Geography of Advanced Producer Services, London: Belhaven Press, pp. 15-30.

Song ML, Yang YJ (2008). "Study of urban competitiveness based on the super-efficiency DEA model". Stat. Educ., 4: 52-54.

Tang QR, Xu XJ (2007). "Research review of producer services". Commer. Time, 6: 11-12. 